\title{
Penggunaan tepung ubi jalar ungu (Ipomoea batatas L) sebagai filler terhadap sifat sensorik sosis daging ayam
}

\author{
I. Sasahan, F.S. Ratulangi*, M. Sompie, J.E.G. Rompis \\ Fakultas Peternakan Universitas Sam Ratulangi Manado, 95115 \\ *Korespondensi (Corresponding author): fsratulangi@ymail.com
}

\begin{abstract}
ABSTRAK
Penelitian ini bertujuan untuk mengetahui bagaimana penggunaan tepung ubi jalar ungu (Ipomoea batatas L) sebagai filler terhadap sifat sensorik sosis daging ayam. Bahan yang digunakan dalam penelitian ini adalah daging ayam segar, tepung ubi jalar ungu, serta bumbu. Penelitian ini menggunakan rancangan acak lengkap (RAL) yang terdiri dari 4 perlakuan. Adapun perlakuannya R1: penambahan tepung ubi jalar $10 \mathrm{~g}$; R2: Penambahan tepung ubi jalar $20 \mathrm{~g}$; R3: penambahan tepung ubi jalar $30 \mathrm{~g}$ dan R4: penambahan tepung ubi jalar $40 \mathrm{~g}$. diuji sensorik melalui 40 orang panelis dengan variabel pengukuran warna, aroma, tekstur, keempukan, citarasa. Data yang diperoleh dianalisis menggunakan anova, dan apabila terdapat perbedaan nyata antar perlakuan dilanjutkan dengan uji berganda Duncan (DMRT). Hasil penelitian ini menunjukan bahwa perlakuan penambahan ubi jalar ungu R1, R2, R3 dan R4 memberikan pengaruh yang berbeda sangat nyata $(\mathrm{P}<0.01)$ terhadap warna, aroma, tekstur, keempukan dan cita rasa pada sosis. Kesimpulan bahwa penambahan tepung ubi jalar ungu 40 g dalam pembuatan sosis daging ayam memberikan sifat sensorik yang baik.
\end{abstract}

Kata kunci : Sosis, tepung ubi jalar ungu, sifat sensorik.

\begin{abstract}
THE USE OF PURPLE SWEET POTATO MEAL (Ipomea batas L) AS A FILLER ON SENSORIC CHARACTERISTIC OF CHICKEN SAUSAGE. This study aims to know how the use of purple sweet potato meal (Ipomoea batatas L) as filler on the sensory characteristic of chicken sausage. The materials used in this study were fresh chicken breast, purple sweet potato meal. The Design of research used in this study was Completely Randomized Design (RAL). The treatment of research were R1: adding purple sweet potato meal $10 \mathrm{~g}$; R2: adding purple sweet potato meal $20 \mathrm{~g}$; R3: adding purple sweet potato meal 30 $\mathrm{g}$ dan R4: adding purple sweet potato meal $40 \mathrm{~g}$. The treatment were tested with sensoric test by 40 panelists. The variables measured in this study were color, aroma, texture, tenderness, taste. The data were analyzed using analysis of variance and then if there was a significant difference of treatment average, it will be continued with Duncan Multiple Range Test (DMRT). The results of this study showed that the addition of purple sweet potatoes to the treatment of R1, R2, R3 and R4 had a very significantly effect $(\mathrm{P}<0.01)$ on the color, aroma, texture, tenderness and taste of the sausage. It could be concluded that the addition of $40 \mathrm{gr}$ of purple sweet potato meal in chicken sausage making provides good sensory properties.
\end{abstract}

Keywords: sausage, purple sweet potato flour, sensory properties. 


\section{PENDAHULUAN}

Sosis merupakan salah satu produk olahan daging yang sangat digemari masyarakat di Indonesia sejak tahun 1980an. Mutu produk makanan terutama sosis sangat dipengaruhi oleh beberapa faktor antara lain rasa, warna, tekstur, nilai gizi, dan mikrobiologisnya (Lawrie, 2003; Anggraeni et al. 2014). Warna merupakan faktor pertama penentu mutu sosis secara visual yang memegang peranan penting terhadap penerimaan konsumen, hal ini disebabkan karena warna merupakan salah satu karateristik sensoris yang paling mudah terdeteksi oleh konsumen dibandingkan dengan karakteristik sensorik lainnya seperti aroma dan tekstur (Soeparno, 2007). Sosis yang bernilai gizi baik, enak, dan teksturnya sangat baik akan diterima oleh konsumen apabila memiliki warna yang tidak menyimpang dari seharusnya (Santoso dan Estiah, 2014; Sembong et al., 2019).

Ubi jalar ungu mengandung sumber karbohidrat yang efisien dibanding dengan tanaman sereal seperti padi (Febri et al., 2019). Ubi jalar ungu mampu menghasilkan kalori $45 \%$ lebih tinggi dari padi. Menurut Sarwono, (2005); Lanusu et al. (2017) bahwa ubi jalar ungu dapat tumbuh baik di dataran rendah maupun di pegunungan. Sejak tahun 1960, ubi jalar ungu sudah tersebar ke beberapa daerah di Indonesia seperti Jawa Barat, Jawa Tengah, Jawa Timur, Papua dan Sumatera. Potensi dari ubi jalar ungu adalah adanya pigmen antosianin pewarna alami yang menghasilkan penampilan menarik pada produk olahan (Apriliyanti, 2010).

Rasa dan aroma yang khas dari ubi jalar ungu dapat meningkatkan sifat sensorik sosis daging ayam. Diversifikasi olahan sosis daging ayam dengan penggunaan tepung ubi jalar ungu sebagai filler diharapakan menjadi bentuk kenakaragaman penyajian sosis yang disukai konsumen. Untuk mengetahui sejauh mana penmanfaatan tepung ubi jalar ungu dapat diterima dalam formulasi sosis sebagai filler telah dilakukan penelitian dengan tujuan menilai kualitas melalui uji uji sensorik penggunaan tepung ubi jalar ungu (Ipomea batatas $L$ ) sebagai filler terhadap sifat sensorik sosis daging ayam.

\section{MATERI DAN METODE PENELITIAN}

Materi yang digunakan pada penelitian yaitu daging ayam segar bagian dada sebanyak $2000 \mathrm{~g}$ dan tepung ubi ungu sebanyak $100 \mathrm{~g}$.

Alat yang digunakan yaitu mixer, alat pengiling daging, selongsong plastik, alat pemecah es, timbangan duduk, kompor gas, water bat, benang woll, Loyang, thermometer, refrigerator. dan alat uji organoleptik yaitu tissue, aqua dan ketimun, kertas kuisioner dan alat tulis.

Penelitian ini dirancang dengan menggunakan rancangan acak lengkap (RAL) (Steel and Torrie, 1994). Data yang diperoleh dianalisis dengan Anova yang terdiri dari 4 perlakuan dengan menggunakan 40 orang panelis tidak terlatih. Adapun perlakuaannya terdiri dari R1: penambahan tepung ubi jalar $10 \mathrm{~g}$; R2: Penambahan tepung ubi jalar $20 \mathrm{~g}$; R3: penambahan tepung ubi jalar $30 \mathrm{~g}$ dan R4: penambahan tepung ubi jalar $40 \mathrm{~g}$. Empat puluh orang panelis tidak terlatih sebagai ulangan. Penelitian ini menggunakan uji mutu hedonik dan apabila terdapat perbedaan antar perlakuan dilakukan uji lanjut DMRT. Susunan perlakuan dapat dilihat pada Tabel 1. Proses pembuatan ubi jalar dapat dilihat pada Diagram 1. Pembuatan sosis dapat dilihat Diagram 2.

\section{Variabel penelitian}

Variabel yang diamati adalah sifat organoleptik daging yaitu warna, aroma, tekstur dan citarasa yang disajikan menggunakan format uji. Penelitian ini menggunakan uji organoleptik dengan skala hedonik $1=$ sangat tidak suka, $2=$ tidak suka, $3=$ agak tidak suka, $4=$ netral, $5=$ agak suka, $6=$ suka, $7=$ sangat suka, 
Zootec Vol. 41 No. 1 : 131 - 138 (Januari 2021) $\quad$ pISSN 0852 - 2626 eISSN 2615 - 869

Tabel 1. Komposisi Bahan Penyusun Sosis Daging Ayam

\begin{tabular}{lcccc}
\hline \multirow{2}{*}{ Bahan } & \multicolumn{4}{c}{ Perlakuan } \\
\cline { 2 - 5 } & $\mathrm{R} 1$ & $\mathrm{R} 2$ & $\mathrm{R} 3$ & $\mathrm{R} 4$ \\
\hline Tepung ubi jalar ungu & $10 \mathrm{~g}$ & $20 \mathrm{~g}$ & $30 \mathrm{~g}$ & $40 \mathrm{~g}$ \\
Daging & $500 \mathrm{~g}$ & $500 \mathrm{~g}$ & $500 \mathrm{~g}$ & $500 \mathrm{~g}$ \\
Bawang putih & $5 \mathrm{~g}$ & $5 \mathrm{~g}$ & $5 \mathrm{~g}$ & $5 \mathrm{~g}$ \\
Bawang merah & $5 \mathrm{~g}$ & $5 \mathrm{~g}$ & $5 \mathrm{~g}$ & $5 \mathrm{~g}$ \\
Merica & $2 \mathrm{~g}$ & $2 \mathrm{~g}$ & $2 \mathrm{~g}$ & $2 \mathrm{~g}$ \\
Garam & $10 \mathrm{~g}$ & $10 \mathrm{~g}$ & $10 \mathrm{~g}$ & $10 \mathrm{~g}$ \\
Gula & $1,5 \mathrm{~g}$ & $1,5 \mathrm{~g}$ & $1,5 \mathrm{~g}$ & $1,5 \mathrm{~g}$ \\
Pala & $0,4 \mathrm{~g}$ & $0,4 \mathrm{~g}$ & $0,4 \mathrm{~g}$ & $0,4 \mathrm{~g}$ \\
Minyak & $20 \mathrm{~g}$ & $20 \mathrm{~g}$ & $20 \mathrm{~g}$ & $20 \mathrm{~g}$ \\
Jahe & $0,5 \mathrm{~g}$ & $0,5 \mathrm{~g}$ & $0,5 \mathrm{~g}$ & $0,5 \mathrm{~g}$ \\
Cengkeh & $0,5 \mathrm{~g}$ & $0,5 \mathrm{~g}$ & $0,5 \mathrm{~g}$ & $0,5 \mathrm{~g}$ \\
Es batu & $60 \mathrm{~g}$ & $60 \mathrm{~g}$ & $60 \mathrm{~g}$ & $60 \mathrm{~g}$ \\
Susu skim & $10 \mathrm{~g}$ & $10 \mathrm{~g}$ & $10 \mathrm{~g}$ & $10 \mathrm{~g}$ \\
\hline
\end{tabular}

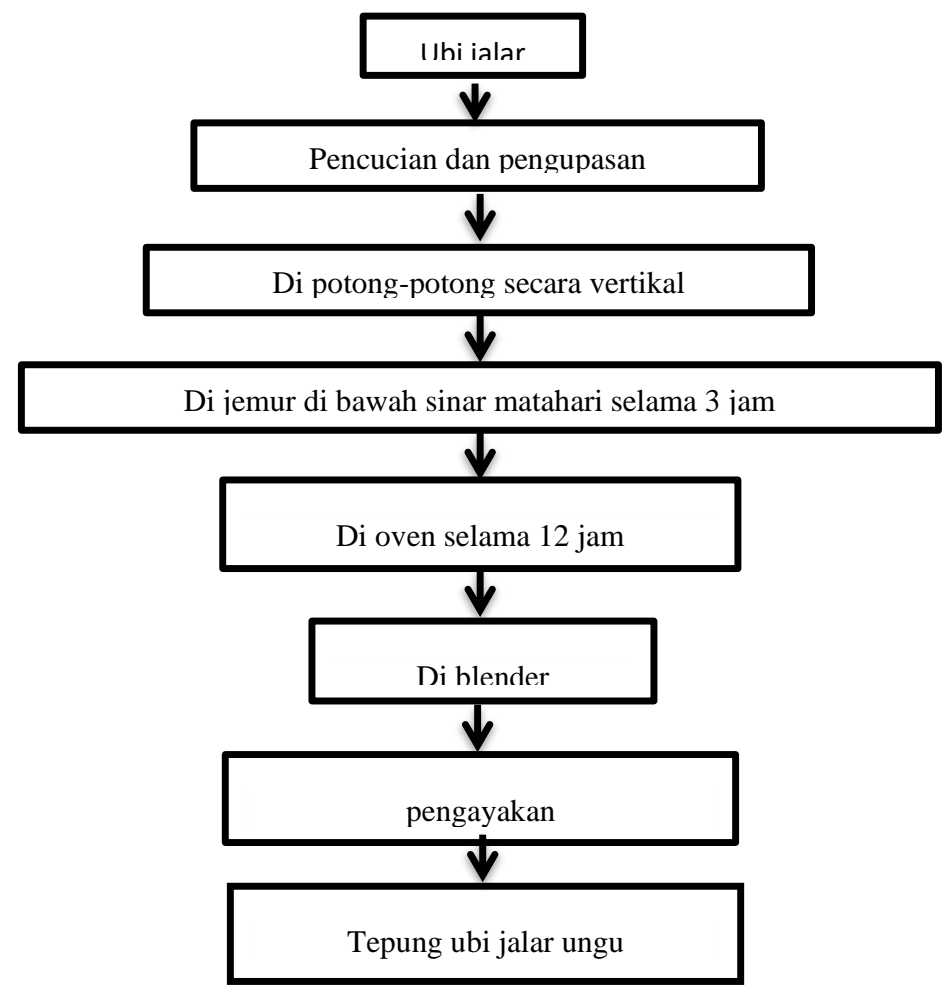

Gambar 1. Diagram alir proses pembuatan tepung ubi jalar ungu 


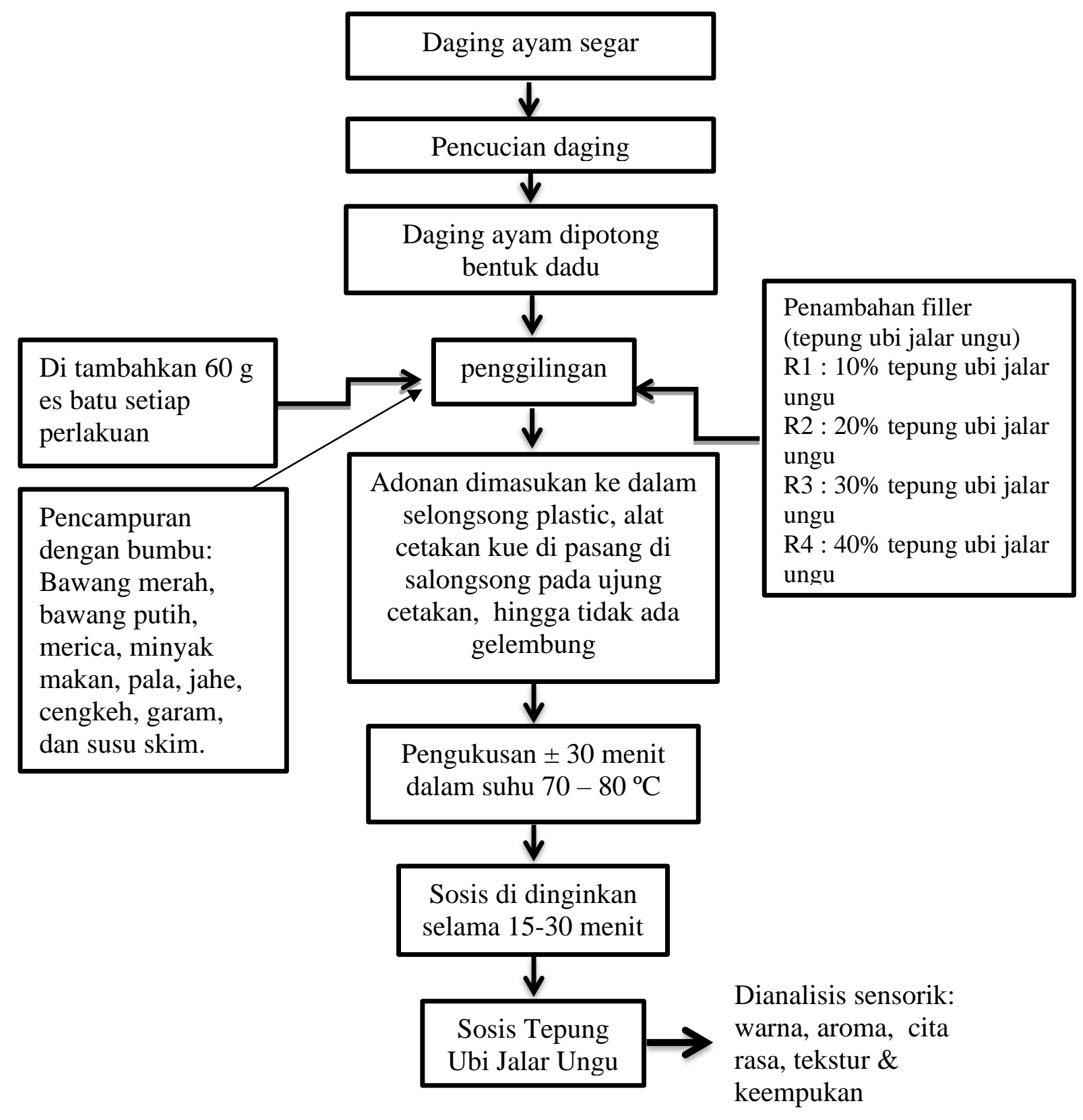

Gambar 2. Diagram alir proses pembuatan sosis tepung ubi jalar ungu 
dan menggunakan panelis tidak terlatih 40 orang (Rahayu, 2001).

\section{HASIL DAN PEMBAHASAN}

Hasil pengamatan sifat sensorik sosis daging ayam dengan penambahan ubi jalar ungu disajikan dalam Tabel 2.

\section{Aroma sosis tepung ubi jalar ungu}

Data hasil pengamatan menunjukkan bahwa rataan tingkat kesukaan panelis terhadap aroma sosis dengan pennggunaan tepung ubi jalar ungu pada konsentrasi yang berbeda berkisar antara 5,38 (agak suka) sampai 6,43 (suka). Nilai rataan skor tertinggi diperoleh pada perlakuan $\mathrm{R} 4$ yakni penambahan tepung ubi jalar ungu 40 $\mathrm{g}$ dan terendah pada perlakuan R2 dengan penggunaan $20 \mathrm{~g}$ tepung ubi jalar ungu.

Berdasarkan hasil analisis sidik ragam menunjukan bahwa perlakuan penggunaan tepung ubi jalar ungu dengan konsentrasi 10-40 g memberikan pengaruh yang berbeda sangat nyata $(\mathrm{P}<0,01)$ terhadap tingkat kesukaan aroma sosis dibandingkan dengan digunakan $10 \mathrm{~g}$ tepung ubi jalar ungu. Hasil uji lanjut menggunakan uji DMRT menunjukan bahwa perlakuan R4 berbeda nyata $(\mathrm{P}<0,05)$ terhadap $\mathrm{R} 1, \mathrm{R} 2$ dan $\mathrm{R} 3$ tetapi R3 tidak berbeda nyata $(\mathrm{P}>0,05)$ terhadap $\mathrm{R} 1$ dan R2. Demikian perlakuan R2 tidak berbeda nyata $(\mathrm{P}>0,05)$ terhadap $\mathrm{R} 1$. Dalam industri pangan, uji aroma sangat penting karena dapat memberikan hasil penilaian penerimaan konsumen terhadap produk yang dihasilkan dengan cepat (Ismanto et al., 2020).

Penggunaan tepung ubi jalar ungu 10$30 \mathrm{~g}$ belum memberikan perbedaan terhadap tingkat aroma. Perbedaan tingkat aroma muncul ketika tepung ubi jalar ungu digunakan pada sosis sebanyak $40 \mathrm{~g}$. Panelis lebih menyukai aroma tepung ubi jalar ungu. Hal ini sejalan dengan pendapat El Husna et al. (2013) bahwa proporsi penggunaan tepung ubi jalar ungu mempengaruhi aroma dari sosis. Semakin banyak proporsi penggunaan tepung ubi jalar ungu maka aroma yang dihasilkan juga semakin kuat. Menurut Widjarnako et al. (2012) dan Ningsih et al. (2017) bahwa aroma produk olahan sosis yang disukai adalah aroma daging

\section{Warna Sosis Tepung Ubi Jalar Ungu}

Data hasil pengamatan menunjukkan tingkat kesukaan panelis terhadap warna sosis dengan pennggunaan tepung ubi jalar ungu pada konsentrasi yang berbeda berkisar antara 4,45 (netral) sampai 5,65 (menarik). Nilai rataan skor tertinggi diperoleh pada perlakuan R4 yakni penambahan ubi jalar ungu $40 \mathrm{~g}$ dan terendah pada perlakuan R1 dengan penggunaan $10 \mathrm{~g}$ tepung ubi jalar ungu.

Hasil analisis sidik ragam menunjukkan bahwa perlakuan penambahan tepung ubi jalar ungu dengan konsentrasi yang berbeda memberikan pengaruh yang berbeda sangat nyata $(\mathrm{R}<0,01)$ terhadap warna sosis daging ayam. Berdasarkan hasil uji lanjut menggunakan uji DMRT menunjukan bahwa perlakuan R4 berbeda nyata $(\mathrm{P}<0,05)$ terhadap $\mathrm{R} 1$ dan $\mathrm{R} 2$ tetapi tidak berbeda nyata $(\mathrm{P}>0,05)$ dengan $\mathrm{R} 3$. Selanjutnya perlakuan R3 berbeda nyata $(\mathrm{P}<0,05)$ dengan $\mathrm{R} 1$ dan $\mathrm{R} 2$, dan juga perlakuan R2 berbeda nyata $(\mathrm{P}<005)$ terhadap R1. Data hasil uji sensorik warna sosis menunjukan bahwa penambahan tepung ubi jalar ungu $40 \mathrm{~g}$ lebih disukai panelis dibandingkan sosis yang ditambahkan $10 \mathrm{~g}$ tepung ubi jalar ungu. Tingkat kesukaan panelis terhadap warna sosis diduga karena tepung ubi jalar mengandung pigmen antosianin yang memberikan warna ungu pada sosis. Panelis memberikan penilaian tingkat kesukaan warna lebih tinggi pada penambahan tepung ubi jalar ungu $40 \mathrm{~g}$ dibandingkan dengan 10 g. Daya tarik warna ungu yang ditampilkan pada R4 memberikan kesan yang paling disukai dibandingkan dengan warna ungu pada perlakuan R1. Menurut Hakim et al. (2013) menyatakan bahwa antosianin merupakan 
Tabel 2. Rataan Sifat Sensorik Sosis Ayam dengan Penambahan Ubi Jalar Ungu

\begin{tabular}{lcccc}
\hline \multirow{2}{*}{ Varibel } & \multicolumn{3}{c}{ Perlakuan } \\
\cline { 2 - 5 } & $\mathrm{R} 1$ & $\mathrm{R} 2$ & $\mathrm{R} 3$ & $\mathrm{R} 4$ \\
& $10 \%$ & $20 \%$ & $30 \%$ & $40 \%$ \\
\hline Aroma & $5,68^{\mathrm{a}}$ & $5,38^{\mathrm{a}}$ & $5,60^{\mathrm{ab}}$ & $6,43^{\mathrm{c}}$ \\
Warna & $4,45^{\mathrm{a}}$ & $4,98^{\mathrm{b}}$ & $5,57^{\mathrm{c}}$ & $6,65^{\mathrm{cd}}$ \\
Cita Rasa & $5,35^{\mathrm{a}}$ & $5,60^{\mathrm{a}}$ & $5,63^{\mathrm{a}}$ & $6,08^{\mathrm{b}}$ \\
Keempukan & $5,48^{\mathrm{a}}$ & $5,55^{\mathrm{a}}$ & $5,60^{\mathrm{a}}$ & $6,05^{\mathrm{b}}$ \\
Tekstur & $5,40^{\mathrm{a}}$ & $5,45^{\mathrm{a}}$ & $5,98^{\mathrm{b}}$ & $6,23^{\mathrm{bc}}$ \\
\hline
\end{tabular}

Keterangan: Superskrip berbeda pada baris yang sama artinya berbeda nyata $(\mathrm{P}<0,05)$

pigmen alami yang berpotensi memberikan warna alami sehingga menghasilkan penampilan yang menarik pada produk olahan. Selanjutnya

Apriliyanti (2010) menyatakan bahwa warna alami dari tepung ubi jalar ungu memberikan intensitas warna ungu yang stabil.

\section{Cita rasa sosis tepung ubi jalar ungu}

Data hasil pengamatan menunjukan bahwa tingkat kesukaan panelis terhadap cita rasa sosis dengan penambahan tepung ubi jalar ungu yang berbeda, terdapat pada kisaran rataan 5,35 (agak enak) sampai 6,08 (enak). Nilai rataan skor tertinggi diperoleh pada perlakuan R4 yakni penambahan tepung ubi jalar ungu $40 \mathrm{~g}$ dan terendah pada perlakuan $\mathrm{R} 1$ dengan penggunaan 10 g tepung ubi jalar ungu.

Hasil analisis sidik ragam menunjukkan bahwa perlakuan penambahan tepung ubi jalar ungu dengan level yang berbeda memberikan pengaruh yang berbeda sangat nyata $(\mathrm{R}<0,01)$ terhadap citarasa sosis yang dihasilkan. Berdasarkan hasil uji lanjut menggunakan uji DMRT menunjukan bahwa perlakuan $\mathrm{R} 4$ berbeda nyata $(\mathrm{P}<0,05)$ terhadap $\mathrm{R} 1$, R2, dan R3. Perlakuan R3 tidak berbeda nyata $(\mathrm{P}>0,05)$ terhadap $\mathrm{R} 1$ dan $\mathrm{R} 2$, juga perlakuan $\mathrm{R} 2$ tidak berbeda nyata $(\mathrm{P}>0,05)$ terhadap R1, dan R2. Penambahan tepung ubi jalar ungu $40 \mathrm{~g}$ pada sosis memberikan daya tarik tersendiri terhadap citarasa dan panelis merekomendasikan bahwa penambahan $40 \mathrm{~g}$ ubi jalar ungu adalah citarasa yang paling disukai. Diduga bahwa tepung ubi jalar ungu merupakan salah satu bahan pangan sumber karbohidrat yang terasa manis dan disukai dalam menentukan citarasa. Hal ini sejalan dengan pendapat Santoso dan Estiasih (2014) menyatakan bahwa pada ubi jalar ungu mengandung senyawa sukrosa yang memberikan efek manis.

\section{Keempukan sosis tepung ubi jalar ungu}

Data hasil pengamatan menunjukan bahwa tingkat kesukaan panelis terhadap keempukan sosis dengan penambahan tepung ubi jalar ungu yang berbeda, terdapat kisaran rataan 5,48 (agak empuk) sampai 6,05 (empuk). Nilai rataan skor tertinggi diperoleh pada perlakuan R4 yakni penambahan tepung ubi jalar ungu 40 $\mathrm{g}$ dan terendah pada perlakuan R1 dengan penggunaan $10 \mathrm{~g}$ tepung ubi jalar ungu.

Hasil analisis sidik ragam menunjukan bahwa perlakuan penggunaan 
tepung ubi jalar ungu 10 - $40 \mathrm{~g}$ memberikan pengaruh yang berbeda nyata $(\mathrm{P}<0,05)$ terhadap keempukan sosis tepung ubi jalar ungu. Berdasarkan hasil uji lanjut menggunakan uji DMRT menunjukan bahwa perlakuan R4 berbeda nyata $(\mathrm{P}<0.05)$ terhadap R1, R2 dan R3. Perlakuan R3 tidak berbeda nyata $(\mathrm{P}>0.05)$ terhadap perlakuan R1 dan R2. Penambahan 10 - 30 g tepung ubi jalar ungu memberikan tingkat penerimaan panelis terhadap keempukan sosis yang sama. Sejalan dengan pendapat Judge et al. (1989), yang menyatakan bahwa tepung ubi jalar ungu mengandung kadar amilopektin yang tinggi, sehingga semakin tinggi level filler yang di berikan maka akan semakin empuk.

\section{Tekstur sosis tepung ubi jalar ungu}

Data menunjukan bahwa tingkat kesukaan panelis terhadap tekstur sosis dengan penambahan tepung ubi jalar ungu yang berbeda, terdapat pada kisaran rataan 5,40 (agak halus) sampai 6,22 (halus). Nilai rataan skor tertinggi diperoleh pada perlakuan R4 yakni penambahan tepung ubi jalar ungu $40 \mathrm{~g}$ dan terendah pada perlakuan $\mathrm{R} 1$ dengan penggunaan $10 \mathrm{~g}$ tepung ubi jalar ungu.

Hasil analisis sidik ragam menunjukan bahwa perlakuan penambahan ubi jalar ungu dengan konsentrasi yang berbeda berpengaruh sangat nyata $(\mathrm{R}<0.01)$ terhadap tekstur sosis yang dihasilkan. Berdasarkan hasil uji lanjut menggunakan uji DMRT menunjukan bahwa perlakuan $\mathrm{R} 4$ berbeda nyata $(\mathrm{R}>0.05)$ terhadap $\mathrm{R} 1, \mathrm{R} 2$ dan R3. Dan perlakuan R3 tidak berbeda nyata $(\mathrm{P}>0.05)$ terhadap $\mathrm{R} 1$ dan $\mathrm{R} 2$. Perlakuan R2 tidak berbeda nyata $(\mathrm{P}>0.05)$ terhadap R1. Penambahan $40 \mathrm{~g}$ tepung ubi jalar ungu memberikan tekstur sosis lebih disukai panelis. Sedangkan penambahan 10-30 g tepung ubi jalar ungu dianggap sama. Menurut Hakim et al. (2013) bahwa unsur karbohidrat pada proses pembuatan sosis berfungsi meningkatkan tekstur dan menstabilkan daya ikat air yang berpengaruh pada tekstur sosis. Selanjutnya
Soeparno (2007) menyatakan tekstur yang lembut pada sosis sangat dipengaruhi oleh komposisi campuran, pengolahan dan penyimpanan.

\section{KESIMPULAN}

Berdasarkan hasil dan pembahasan bahwa penambahan ubi jalar ungu $40 \%$ dalam sosis memberikan sifat sesorik yang baik.

\section{DAFTAR PUSTAKA}

Anggraeni, D.A., S. B. Widjanarko dan D. W. Ningtyas. 2014. Proporsi tepung porang (Amorphophallus muelleri Blume): tepung maizena terhadap karakteristik sosis ayam. Jurnal Pangan dan Agroindustri 2(3): 214223

Apriliyanti, T. 2010. Kajian sifat fisikokimia dan sensori tepung ubi jalar ungu (Ipomoea batatas blackie) dengan variasi proses pengeringan. Skripsi. Program Studi Teknologi Pertanian. Fakultas Pertanian. Universitas Sebelas Maret, Surakarta.

El Husna, N., M. Novita dan S. Royana. 2013. Kandungan antosianin dan aktivitas antioksidan ubi jalar ungu segar dan produk olahannya. Jurnal Teknologi Pangan 33(3): 2680-5194

Febri, Y., G.E.M. Malelak dan Y.R. Noah. 2019. Pengaruh penggunaan tepung ubi jalar ungu (Ipomoea batatas lam poir) sebagai pengganti tepung tapioka terhadap kualitas sosis babi. Jurnal Peternakan Lahan Kering 1(3): 475-482

Hakim U. N., Djalal R. dan Aris S. W. 2013 Pengaruh Penambahan Tepung Garut (Maranta arrundinaceae) Terhadap Fisik Organoleptik Nugget kelinci. Jurnal Ilmu dan Teknologi Pangan 1(4): 29-38

Ismanto, A., D. P. Lestyanto, M. I. Haris, Y. Erwanto. 2020. Komposisi Kimia, Karakteristik Fisik, dan Organoleptik 
Sosis Ayam dengan Penambahan Karagenan dan Transglutaminase. Sains Peternakan 18(1): 73-80

Judge, M.D., E.D. Aberle, J.C. Forrest, H.B. Hedrick, and R.A. Merkel. 1989. Principles of meat Science. $2^{\text {nd }}$ ed. Kendall Hunt Publising Company, Derbuque, Lowa.

Lanusu, A., S.E. Surtijono, L.C.M. Karisoh dan E.H.B. Sondakh. 2017. Sifat organoleptik es krim dengan penambahan ubi jalar ungu (Ipomea batatas L). Zootec 37(1): 474-482

Lawrie, R. A. 2003. Ilmu Daging. Terjemahan: Aminuddin Parakkasi. Penerbit Universitas Indonesia Press, Jakarta.

Nilasari, 2012. Pengaruh penggunaan tepung ubi jalar, garut dan onggok terhadap sifat fisik dan lama penyimpanan ayam broiler bentuk fellet. Skripsi. Departemen Ilmu Nutrisi dan Teknologi Pakan, Fakultas Peternakan IPB, Bogor.

Ningsih, S., J.E.G. Rompis, E.H.B. Sondakh, N. Lontaan. 2017. Pengaruh penggunaan tahu sebagai extender terhadap sifat organoleptic sosis ayam. Zootec 37(2): 341-349.

Rahayu, W. P. 2001. Penuntun Praktikum Penilaian Organoleptik. Jurusan Teknologi Pangan dan Gizi. Fakultas Teknologi Pangan. IPB. Bogor

Santoso, W. E. A. dan T. Estiasih. 2014. Kopingmentasi ubi jalar ungu (Ipomea Batatas Var. Ayamurasaki) dengan kopingmentasi na-kaseinat dan protein whey serta stabilitasnya terhadap pemanasan. Fakultas Teknologi Pertanian Universitas Brawijaya, Malang. Jurnal Pangan dan Agroindustri, 2:121-127

Sembong, R., S. Peka, P. Kale dan G. Malelak. 2019. Kualitas sosis babi yang diberi tepung talas sebagai pengganti tepung tapioka. Jurnal Nukleus Peternakan 6(1): 1-9

Sarwono, B. 2005. Ubi Jalar, Cara Budidaya yang Tepat, Efisien dan
Ekonomis. Penebar Swadaya. Jakarta.

Soeparno. 2007. Pengolahan Hasil Ternak. Gadjah Mada Press. Yogyakarta.

Steel, R.D. dan J.H. Torrie 1994. Prinsip dan Prosedur Statistika Suatu Pendekatan Biometrik. Edisi kedua. Diterjemahkan oleh Bambang Sumantri Jakarta: PT. Gramedia.

Wahyuni, D., Setiyono dan Supadmo. 2012. Pengaruh penambahan angkak dan kombinasi filler tepung terigu dan tepung ketela rambat terhadap kualitas sosis sapi. Buletein Peternakan Vo. 36 (3): 181-192.

Widjanarko, B. S., E. Zubaidah dan A. M. Kusuma. 2012. studi kualitas fisikkimiawi dan organoleptik sosis ikan lele dumbo (Clarias gariepinus) akibat pengaruh perebusan, pengukusan dan kombinasinya dengan pengasapan. Jurusan Teknologi Hasil Pertanian, FTP Unibraw. J. Tek. Pert. 4(3): 193-202 